\title{
A NEW SPECIES OF VANILLA FROM SOUTH AMERICA ${ }^{1}$
}

\author{
Miguel A. Soto Arenas† \\ Herbario AMO, Montañas Calizas 490, México D.F. 11000, México
}

\begin{abstract}
A new species from the basin of the Rio Magdalena in northern Colombia is proposed, Vanilla espondae.
\end{abstract}

Key Words: Orchidaceae, Vanilla, V. espondae, Rio Magdalena, Colombia

During my work with the phylogeny of Vanilla it became evident that some specimens represent undescribed species in the genus. The species here described is among the most showy in the genus, suggesting that additional, undescribed vanillas may be remain to be found*.

The taxon is native to South America, where Vanilla reaches its highest diversity, and from where much more material is needed. Its relationships are discussed.

Vanilla espondae Soto Arenas, sp. nov.

HOLOTYPE: [N.] Colombia: Tributary of R. Magdalena, cult. F. Pérez-Vera 563, K-L! (illustration voucher).

A Vanillae trigonocarpae Hoehne disco labelli papillis verrucisque ornato recedit.

Hemi-epiphytic herb. Stems apparently thin, terete, smooth, olive green, $c a .6 .3 \mathrm{~mm}$ thick, the internodes as long as the leaves. Leaf shortly petiolate, the petiole $c a .8 \mathrm{~mm}$ long, blade oblanceolate, abruptly acuminate, the apex incurved, base obtuse, the basal margin revolute, coriaceous-fleshy, green, $14.5 \mathrm{x}$ $3.6 \mathrm{~cm}$. Inflorescence axillary, a shortly pedunculate

${ }^{1}$ Editor's note: Miguel Angel Soto Arenas passed away August $27^{\mathrm{h}}, 2009$. We wish to thank Dr. Phillip Cribb for preparing the camera lucida drawing of the lip of the holotype, and Rolando Jiménez Machorro for preparing the attached illustration, prepared from a digital image of the holotype and the rendering of the lip by Dr. Cribb.

* Editor's note: Additional new species from Mexico and Central America are being described elsewhere in this issue: see Soto Arenas \& Dressler, pp. 285-354. raceme, the rachis congested, with ca. 11 flowers, bracts unknown. Ovary sub-trigonous conspicuously white. Flowers: buds whitish at base, apex green, with the midrib of petals protruding between the sepals; flowers very showy, large, perhaps $12-15 \mathrm{~cm}$ diameter when spread out; tepals ivory white, outer, basal surface of the lip ivory-white, mid lobe and throat ivory-white lined with yellow-ochre, papillae of the midlobe yellow; the segments spreading. Dorsal sepal recurved, apparently long oblanceolate, acute, perhaps as long as the lateral ones. Lateral sepals directed downwards, somewhat falcate, obliquely oblanceolate, obtuse-subacute, base long attenuate, with a prominent axial vein on the abaxial surface and corresponding to the axial groove on the adaxial surface; very smooth, $74-78 \times 20 \mathrm{~mm}$. Petals spreading, somewhat arcuate, slightly recurved at the apex, narrowly elliptic-oblanceolate, acuteacuminate, convex, apically conduplicate, broader than the sepals, longitudinally keeled on the outer surface, the keel broad and conspicuous, at least 76 long, more than $16 \mathrm{~mm}$ wide (not well preserved). Lip very showy, forming a long tube, marginally fused to the column at least $2.7-2.9 \mathrm{~cm}$; when spread out trilobed, the lateral lobes scarcely defined with rounded shoulders, oblong-triangular, tapering at apex, $c a .28 \times 12 \mathrm{~mm}$; midlobe oblong, rounded, the base somewhat narrowed and forming an isthmus, ca. $16 \times 15 \mathrm{~mm}$; the disc covered by 7 showy rows of papillae, longer towards the apex, the papillae digitiform, up to $3.5 \mathrm{~mm}$ high, continuous with warty veins at the apex of the midlobe. Column unknown.

Etymology: This species is dedicated to my dear friend Mrs. Nora Esponda, administrative assistant at 


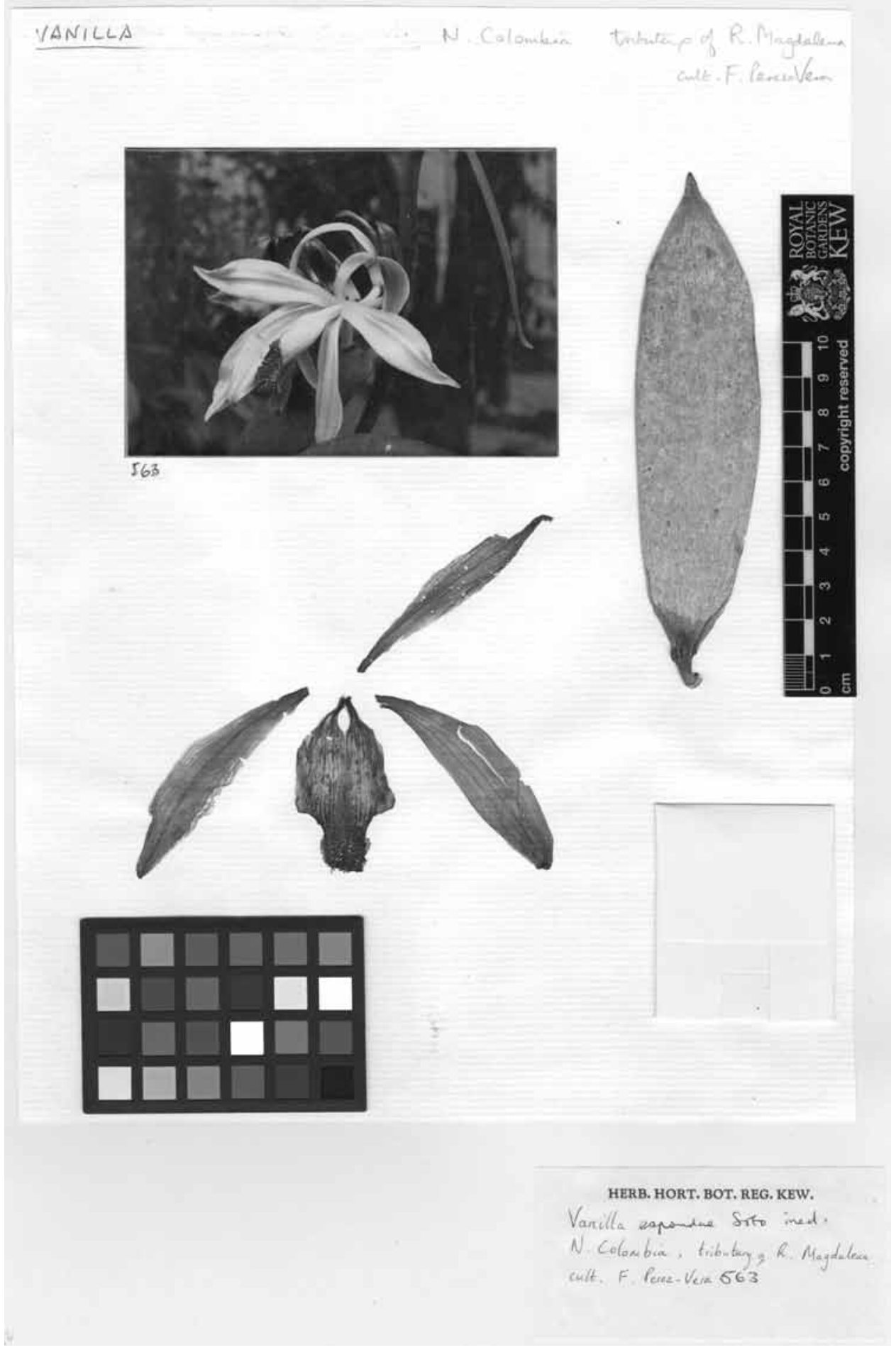

FIgURE 1. Holotype of Vanilla espondae Soto Arenas, by permission of the Keeper, Herbarium, Royal Botanic Gardens, Kew. 

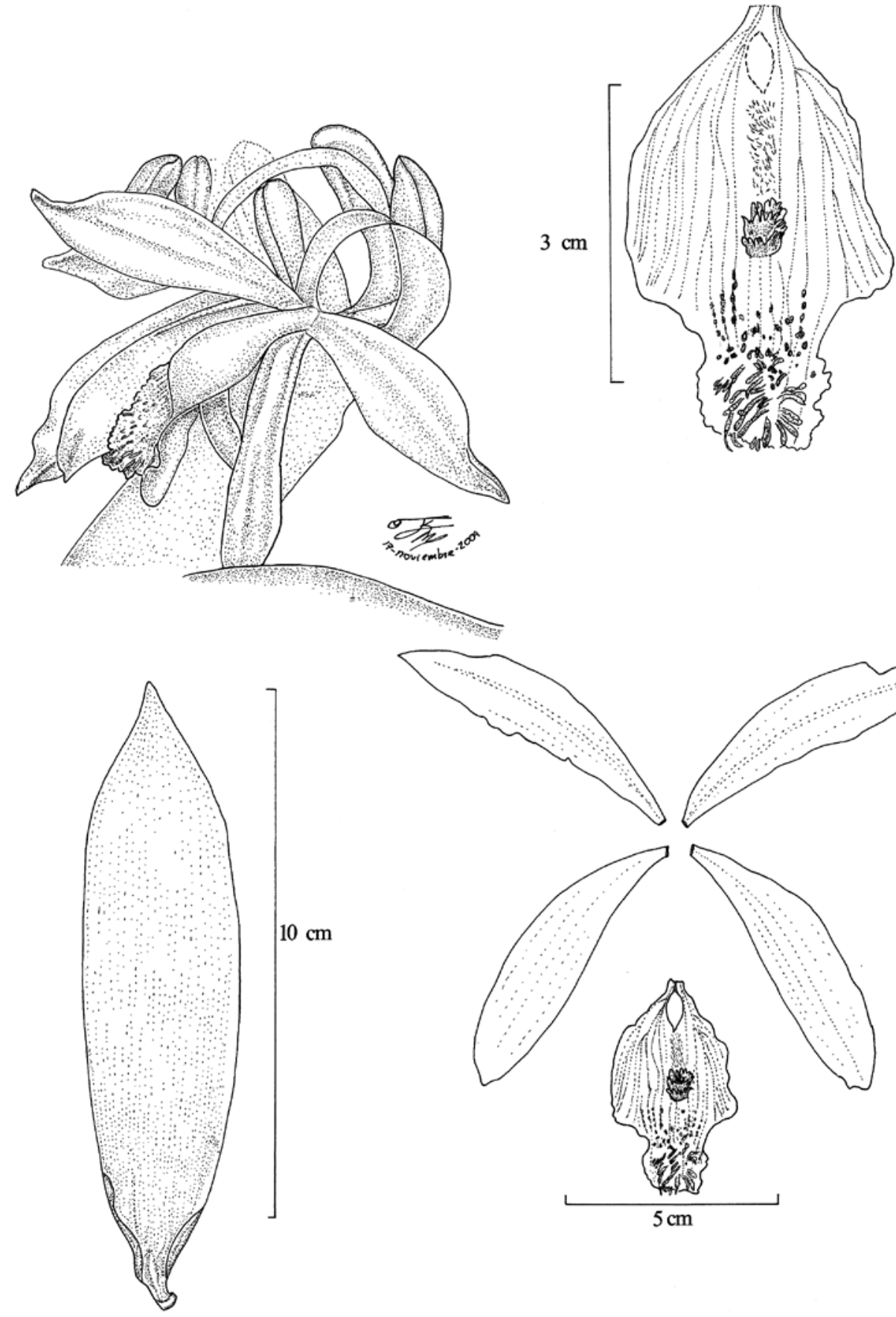

FIGURE 2. Vanilla espondae Soto, prepared from the holotype by Rolando Jiménez M.; the lip based on a camera lucida drawing by P. Cribb.

the Herbario AMO. Nora's work is evident in every product of our team and she has been of indispensable assistance during our research work.
Distribution: Known only from the type; from the basin of the Río Magdalena in northern Colombia. 
This is one of the most beautiful Vanilla species. Although it is not closely related to any other Vanilla, it could be allied to V. trigonocarpa, with which it shares the huge, whitish flowers, and bright yellow disc; $V$. trigonocarpa lacks the papillae and warts on the disc. Other species with similarly adorned lips, like $V$. helleri A.D.Hawkes or $V$. insignis Ames, have either smaller flowers or green tepals.

The type specimen consists only of a single leaf, a picture of the inflorescence, the 2 lateral sepals, a petal, and the lip, yet the species is so different from any other described species of Vanilla, that I have little hesitation in proposing it. 